\title{
A Case of Organized Hematoma after Coblation Assisted Turbinoplasty
}

\author{
Ji Sung Shim, Seung Yong Oh, Jong Yang Kim, and Woo Hyun Lee \\ Department of Otolaryngology, National Police Hospital, Seoul, Korea
}

\author{
Coblation을 이용한 하비갑개 수술 후 발생한 기질화 혈종 1예 \\ 심지성 · 오승용 · 김종양 · 이우현 \\ 국립경찰병원 이비인후과
}

\author{
Received May 7, 2016 \\ Revised August 8, 2016 \\ Accepted August 11, 2016 \\ Address for correspondence \\ Woo Hyun Lee, MD \\ Department of Otolaryngology, \\ National Police Hospital, \\ 123 Songi-ro, Songpa-gu, \\ Seoul 05715, Korea \\ Tel $+82-2-3400-1399$ \\ Fax $+82-2-400-0287$ \\ E-mail sniper212@hanmail.net
}

Organized hematoma of nasal cavity has been reported previously in several articles. However, few studies reported the cause of organized hematoma. Recently, 22-years-old male who underwent coblation associated turbinoplasty one year ago visited our clinic with symptom of nasal obstruction. He was diagnosed as organized hematoma in left maxillary sinus. We performed endoscopic sinus surgery and successfully removed it. Therefore, we report a case of organized hematoma origin from maxillary sinus after coblation associated turbinoplasty. Korean J Otorhinolaryngol-Head Neck Surg 2017;60(2):87-9

Key Words Maxillary sinus · Organized hematoma · Turbinoplasty.

\section{서 론}

기질화 혈종은 인체의 다양한 장소에서 발생할 수 있는 비 교적 드문 양성질환으로 여러 원인으로 인해 혈종이 형성된 후 내부에 혈관의 신생 및 조직의 섬유화가 진행되며 종괴의 형태로 나타나는 질환이다. ${ }^{1,2)}$ 부비동 및 비중격에서 발생한 기 질화 혈종의 경우 종괴가 커짐에 따라 비폐색, 반복되는 비출 혈 및 비루 등의 증상이 나타날 수 있으며 상악동이나 비중격 의 구조적 변형을 야기할 수 있다. ${ }^{3,4)}$ 지금까지 비강에서 발생 한 기질화 혈종은 국내 및 국외에서 여러 차례 보고가 되었으 나 그 구체적인 원인에 대한 논문 보고는 거의 없었다. 저자들 은 코블레이터(coblator)를 이용한 하비갑개 축소술 후 발생한 상악동 기원의 기질화 혈종을 경험하였고 이러한 경우는 현재 까지 보고된 적이 없었기에 문헌고찰과 함께 보고하는 바이다.

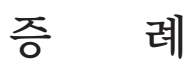

22세 남자가 내원 1년 전부터 심화되는 좌측 코막힘을 주
소로 내원하였다. 환자는 1년 전 만성비염으로 개인병원에서 코블레이터를 이용한 하비갑개 성형술을 시행받았으며 수술 이후 좌측 비폐색이 점차 심해져 추가적인 검사 및 치료를 위해 본원을 방문하였다. 과거력상 비염 외 특이질환은 없었 고 이전의 안면 및 부비동의 수술이나 외상의 과거력은 없었 다. 또한 가족력상에서도 특이사항은 없었으며, 일반 혈액검 사 및 일반 화학검사, 혈청검사 및 혈액응고검사상에서도 특 이소견은 보이지 않았다. 비강 내시경 소견상 좌측 하비갑개 전방부에 코블레이터 삽입 위치로 보이는 반흔조직이 관찰되 었으며 하비갑개 후방부의 비후소견이 관찰되었고 비후조직 으로 인해 중비도 및 후비강의 확인은 불가능하였다(Fig. 1). 우측 비강은 심한 비중격의 우측편위 소견을 보였고 종물 등 의 특이소견은 보이지 않았으며 비인두에도 특이소견은 관찰 되지 않았다. 조영제를 사용한 부비동 전산화단층촬영에서 좌측 상악동을 가득 채운 균일하지 않게 조영 증강된 종괴 가 관찰되었으며 종괴는 상악동 내측벽을 밀어내며 팽창하는 양상을 보였다(Fig. 2). 좌측 전사골동부 일부에 부비동염 소 견 외 나머지 부비동에 이상소견은 보이지 않았으며 안와저 
골부의 침범소견도 관찰되지 않았으나 팽창성 종괴에 의해 비중격이 반대편으로 밀리는 소견이 관찰되었다. 혈관종이나 반전형 유두종 및 신경섬유종, 기질화 혈종 등이 의심되어 진 단 및 치료를 위해 전신마취 하에 내시경적 접근을 통한 종 괴의 절제술을 계획하였다. 수술 시 비강을 통해 내시경 접근 법으로 종괴의 변연을 확인하였고 좌측 상악동의 내측 후방 기원의 종괴임을 확인한 뒤 회전절삭기 및 소작기를 사용하 여 종괴를 조각 내어 제거하였다. 혈종 발생부위는 상악동 내측 후방부였으며 박리과정에서 접형구개동맥의 분지로 추 정되는 동맥의 출혈이 발생하여 흡입기가 연결된 단극성 소작 기를 통해 출혈을 조절하였다. 배출된 종괴의 내부는 혈관이 잘 발달되어 있었고 섬유화가 진행되어 단단한 질감이었으며 종괴의 외측부에는 점액성 액체가 포함된 점액낭종이 일부 관찰되었다(Fig. 3). 술 후 병리조직학적 소견에서 종괴는 내부

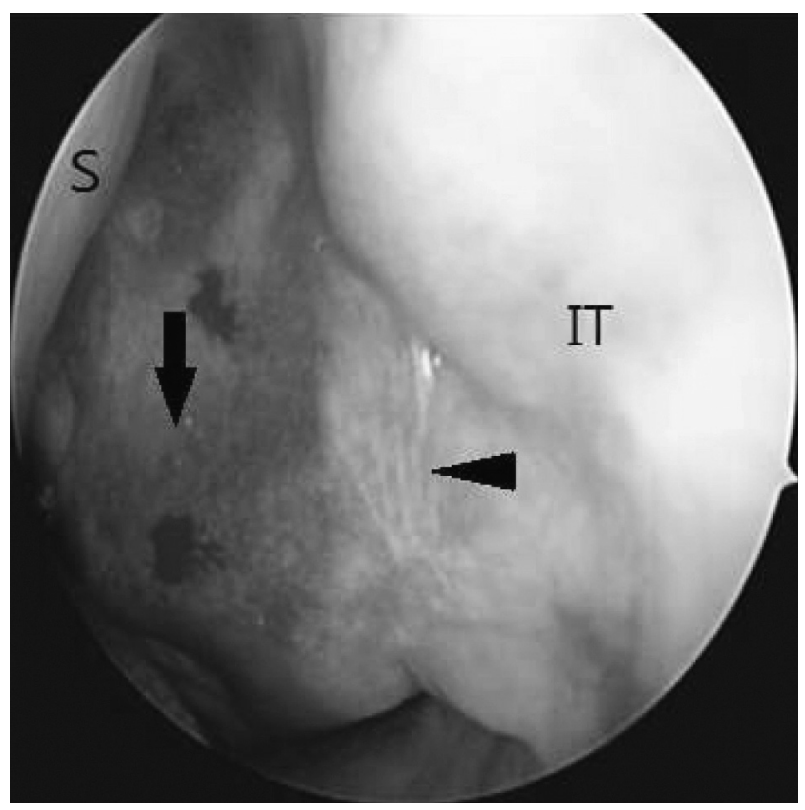

Fig. 1. Preoperative endoscopic findings. The arrowhead indicates coblation scar. The arrow shows mass filled the left nasal cavity. IT: inferior turbinate, S: nasal septum.
에 풍부한 신생혈관들과 섬유화가 관찰되어 기질화 혈종으로 진단되었다(Fig. 4). 수술 이후 환자의 코막힘 증상은 사라졌 으며 6개월간 추적관찰을 한 결과 종괴의 재발소견은 보이지

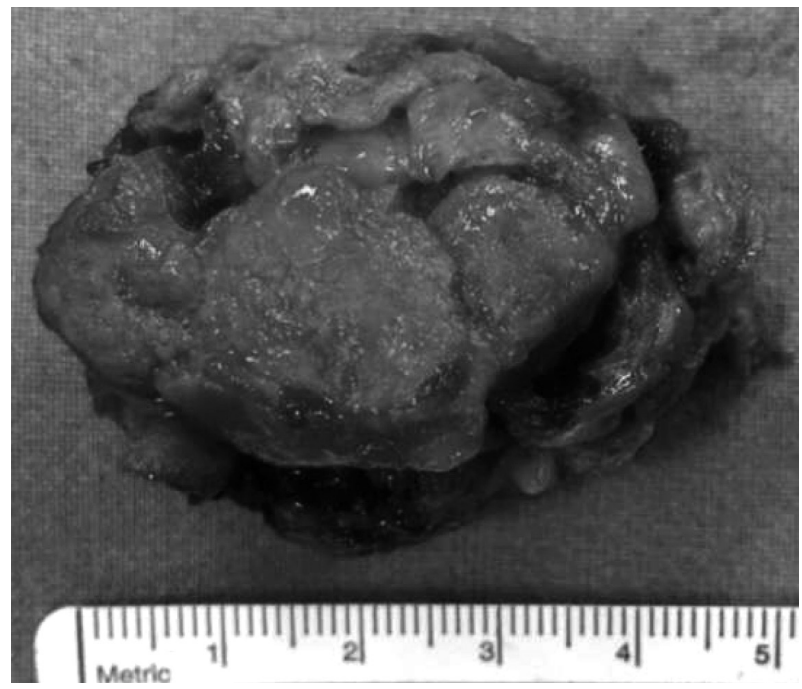

Fig. 3. Gross image of the excised mass. Mass including fibrotic tissue with neovascularization.

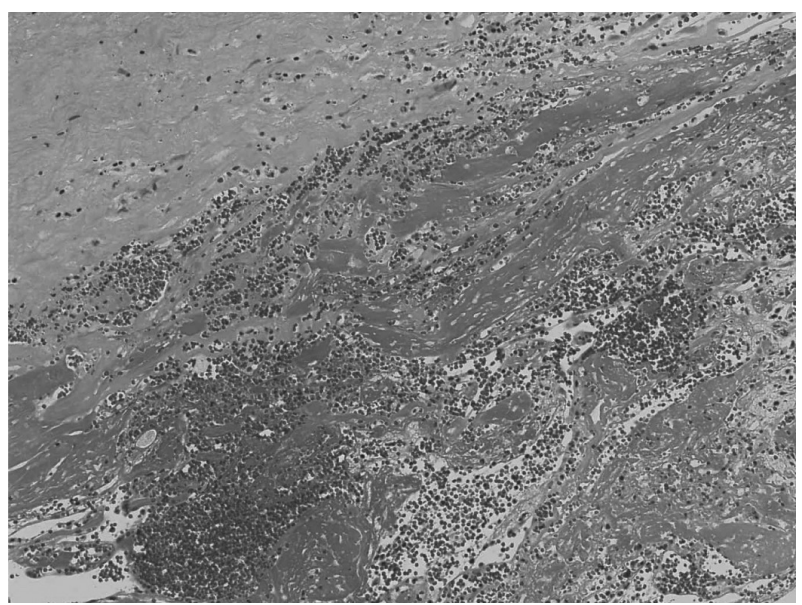

Fig. 4. Histopathologic finding of organized hematoma. We can find organized hematoma including neovascularization and fibrosis (H\&E stain, $\times 100)$.
Fig. 2. Preoperative CT findings. The image show about $35 \times 50 \times 32$ $\mathrm{mm}$ sized soft tissue mass lesion with heterogenous enhancing portions. Left maxillary sinus medial wall was partially destructed.
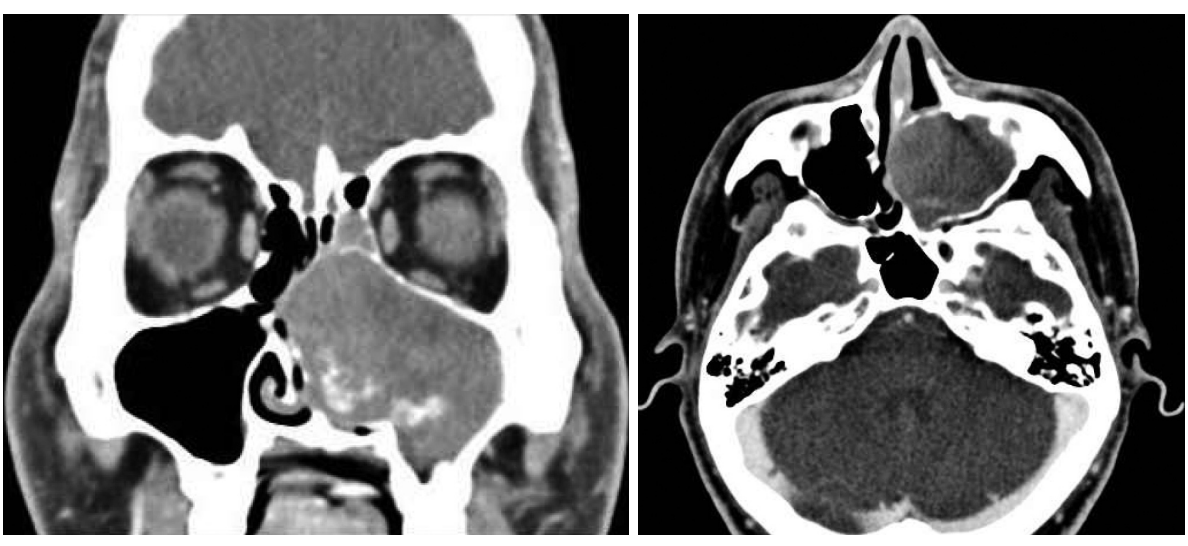
Fig. 5. Postoperative CT findings. The mass was completely removed and nasal septum returns natural position.
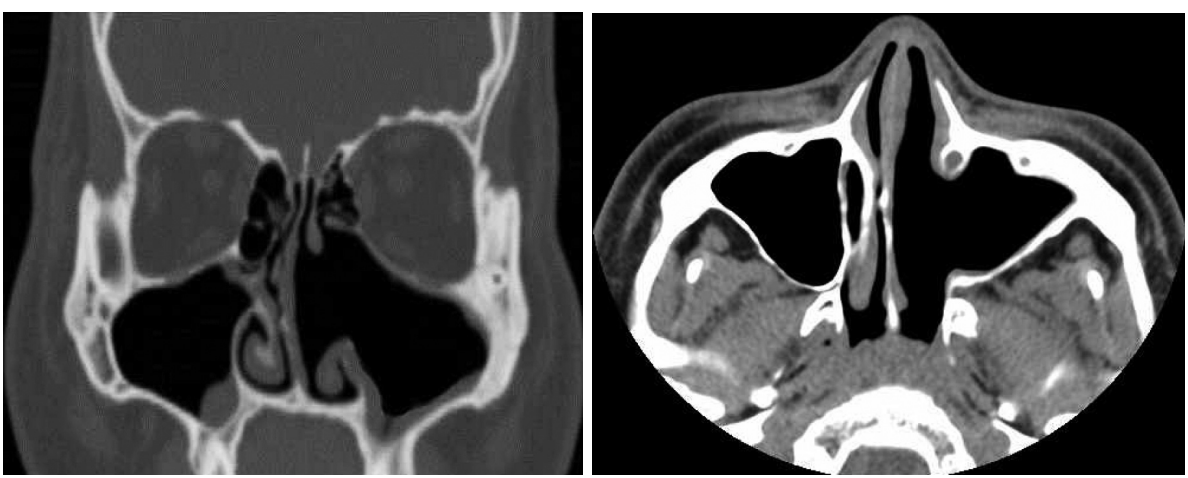

않았고 부비동 전산화단층촬영상 비중격의 우측 편위도 다 소 정상으로 돌아온 것이 확인되었다(Fig. 5).

\section{고 찰}

기질화 혈종은 다양한 원인에 의한 출혈로 인한 혈종의 형 성이 일차적으로 선행되어 발생하는 것으로 알려져 있으며, 상악동 내에 발생한 혈종의 기원에 대한 기전은 비강 내 출혈 이 상악동 내로 유입된 경우 및 상악동 내 혈관의 파열로 인 해 상악동 점막하 출혈이 발생한 경우 등이 있다.5,6) 혈종이 형 성되면 혈종 내부의 불완전한 환기 및 배액으로 인한 혈관의 신생이 나타나고 섬유화가 진행되는 기질화 과정을 통해 종괴 의 양상을 나타내는 것으로 생각된다." 본 증례의 경우 일차 적 출혈의 발생부위가 접형구개동맥 분지부로 의심되며 해당 부위는 1년 전 하비갑개 수술 시 코블레이터 탐침부에 의해 손상이 발생하였을 것으로 추정된다. 환자의 하비갑개 전방 부의 반흔과 혈종 기시부는 일직선상에 위치하고 있어 코블 레이터 탐침부의 과도한 침투에 의해 점막부의 손상 및 점막 하 출혈이 발생하였을 가능성이 높아보인다. 기질화는 1 년 동 안 지속적으로 진행되었을 것으로 추정되나 병력청취상 당시 수술 이후 1 개월 내에 비폐색이 재발하였다는 것으로 보아 비 교적 빠른 시간 내에 종괴의 증대가 일어났을 것으로 추정된 다. 종괴의 발생 및 진행속도에 관해 통계적으로 보고된 논 문은 없지만 최근 발표된 증례보고에 따르면 8개월 이내에 급격히 종괴가 팽창하며 안와 등 주변구조물의 파괴 및 합병 증을 야기한 경우도 있다. ${ }^{8)}$

기질화 혈종의 진단은 병력청취 및 내시경 소견, 영상검사 등을 통해 유추해 볼 수 있지만 육안적으로 혈관종이나 반전 형 유두종, 화농성 육아종, 신경섬유종 또는 기타 악성종양 과 정확한 감별진단이 어렵다. 따라서 전적출술 이후 생검을 통해 확진이 되는 경우가 대부분이지만, 본 증례와 같이 이전
에 비강 내 점막손상의 가능성이 있는 환자의 경우는 기질화 혈종을 우선 의심해 볼 수 있을 것이라 생각된다. 기질화 혈 종 자체는 침투성이 없는 양성질환으로 분류되나 치료시기 가 지연되면 종괴의 압박으로 인한 주변 조직이나 장기의 손 상이 야기될 수 있으므로 의심되는 환자는 적극적으로 수술 을 통한 진단 및 치료가 이루어져야 한다." 나아가 코블레이 터를 이용한 하비갑개 성형술은 이비인후과 비과영역에서 보 편적으로 사용되는 술기인 만큼 과도한 조작으로 인한 합병 증의 발생에 주의해야 할 것으로 생각되며 수술 후 합병증에 비록 드물지만 기질화 혈종을 포함시키는 것도 논의되어야 할 사항이라고 생각된다.

\section{REFERENCES}

1) Lee HK, Smoker WR, Lee BJ, Kim SJ, Cho KJ. Organized hematoma of the maxillary sinus: CT findings. AJR Am J Roentgenol 2007; 188(4):W370-3.

2) Lee BJ, Lee YS, Heo SC, Kim JH, Kim YJ. Organizing hematoma of the maxillary sinus. Korean J Otolaryngol-Head Neck Surg 2002; 45(3):245-8.

3) Ozhan S, Araç M, Isik S, Oznur II, Atilla S, Kemaloglu Y. Pseudotumor of the maxillary sinus in a patient with von Willebrand's disease. AJR Am J Roentgenol 1996;166(4):950-1.

4) Unlu HH, Mutlu C, Ayhan S, Tarhan S. Organized hematoma of the maxillary sinus mimicking tumor. Auris Nasus Larynx 2001;28(3): 253-5.

5) Park EH, Lee SS, Sung SH. Maxillary sinus mucocele secondary to organized hematoma. Korean J Otorhinolaryngol-Head Neck Surg 2007;50(11):1073-6.

6) Hsu WS, Liu SF, Chu ST, Tseng HH. An organizing hematoma in the parapharyngeal space. J Chin Med Assoc 2009;72(2):94-7.

7) Ha MS, Song YJ, Han KY, Yeo NK. A case of organizing hematoma of the nasal septum. Korean J Otorhinolaryngol-Head Neck Surg 2010;53(5):324-6.

8) Yoon TM, Lee DH, Kim SB, Lim SC. Organized hematoma of the maxillary sinus: rapid progression and complications. Korean J Otorhinolaryngol-Head Neck Surg 2016;59(2):150-4.

9) Choi SJ, Seo ST, Rha KS, Kim YM. Sinonasal organized hematoma: clinical features of seventeen cases and a systematic review. Laryngoscope 2015;125(9):2027-33. 